COGNitive Studies | Études COGNITIVES, 14: 173-182 SOW Publishing House, Warsaw 2014

DOI : $10.11649 / \mathrm{cs} .2014 .014$

\author{
DANUTA ROSZKO ${ }^{1, A} \&$ ROMAN ROSZKO ${ }^{1, B}$ \\ ${ }^{1}$ Institute of Slavic Studies, Polish Academy of Sciences Warszawa, Poland \\ ${ }^{A}$ danuta.roszko@ispan.waw.pl ; ${ }^{B}$ roman.roszko@ispan.waw.pl

\section{A NET PRESENTATION OF LITHUANIAN SENTENCES CONTAINING VERBAL FORMS WITH THE GRAMMATICAL SUFFIX - $D A V$ -}

\begin{abstract}
In the article the authors make an attempt to present the meaning of Lithuanian sentences containing verbal forms with the grammatical suffix - dav- (the so-called iterative past tense forms) by means of Petri nets. The authors gradually develop the net to such complexity that it makes it possible to avoid interpretative similarities to other Lithuanian verbal forms.

Keywords: Petri nets, the aspect and tense, the Lithuanian language, verbal forms with the suffix -dav- (the so-called iterative past tense).
\end{abstract}

\title{
Introduction
}

The description of tense-reference issues in natural language requires a move away from the well-known linear Reichenbach theory, replacing it with two alternative theories:

- processes known as Petri nets, which describe aspect-tense sentence relations.

- range quantification, which describes the definiteness and indefiniteness values of sentence verbum groups. (Petri, 1962; Koseska \& Mazurkiewicz, 2010; Koseska, 2014).

The Reichenbach theory worked well in the description of English tense-reference forms. However, applying it to other languages does not always result in an accurate description. The grammatical category of aspect which has developed in such languages as Polish or Lithuanian, imposes a quite different set of requirements on the theory to describe tense in its inseparable connection with aspect. An attempt to use segment theory (rather than linear theory) also attests to the limited capabilities of the Reichenbach theory in the description of aspect-tense issues conducted by Z. Guentchéva (2003). 
1 A basic net presentation of sentences constructed on Lithuanian verbal forms with the grammatical suffix -dav-

The Lithuanian verbal formation with the suffix -dav- is one of several synthetic Lithuanian verbal forms. Its usage is accompanied by reference to the past. The simplest net presentation of the model sentence Tomas skaitydavo seneliams laiškus. (Tom used to read letters to his grandparents.) can assume the form presented in figure 1.

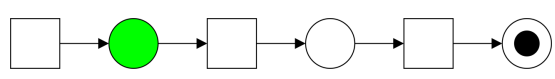

Legend

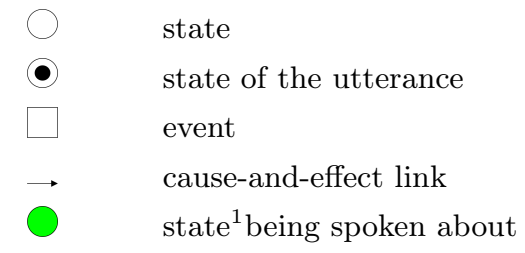

Figure 1 Net presentation of the Lithuanian sentence Tomas skaitydavo seneliams laiškus. 'Tom used to read letters to his grandparents.'

In the net presented in figure 1, the following features of the model sentence become apparent:

- The continuity of the state (marked with green colour).

- The past (expressed by the mutual location of the states - the one marked with green and that of the utterance - as well as the events and arrows determining cause-and-effect links, which are also referred to as sequentiality links).

It is worth emphasizing the fact that the state marked with green does not come immediately before the state of the utterance. Both states are divided by an additional state (exactly: event $\rightarrow$ state $\rightarrow$ event), which explicitly places the green state in a more distant past, not immediately before the state of the utterance. The net described in figure 2 excludes an interpretation typical of the model sentence, because the contents conveyed by the Lithuanian verbal forms with the grammatical suffix -dav-explicitly exclude the direct vicinity of the state of the utterance and the past state described by the sender.

A question arises whether the net described in the scheme explicitly identifies the meaning of sentences containing verbal forms with the grammatical suffix - dav-. The answer to this question is not yet possible at this stage of the description.

\footnotetext{
${ }^{1}$ The state in Petri nets is understood dynamically. The state is characterized by continuance. An example of the state can be $<$ reading a book by John $>$ as well as $<$ John's growing up $>$. However, the event is timeless. The event terminates one state and simultaneously begins another one. More widely on the Petri nets theory and its use for the description in the natural language comp. (Mazurkiewicz, 1986; Koseska \& Mazurkiewicz, 2010).
} 


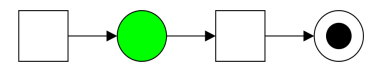

Figure 2 A net presentation variant of the meaning of the past tense, excluding the description of the meaning of the Lithuanian form with the grammatical suffix $-d a v-$

2 Mutual exclusivity of the sentence contents based on the verbal forms with the grammatical suffix -dav- and of the present and future tense forms

Let us check whether the conversion of the verbal form with the grammatical suffix -dav- to the present or future tense form results in a different net presentation:

Tomas skaitydavo seneliams laiškus. $\rightarrow$ Tomas skaito (form of the present tense) seneliams laiškus.

Tomas skaitydavo seneliams laiškus. $\rightarrow$ Tomas skaitys (form of the future tense) seneliams laiškus.

The net presentation of the two new sentences is given in figures 3 and 4 . The state marked with red colour (see fig. 3) is concurrent with the state of the utterance, which excludes the situation presented in figure 1, in which the state marked with green precedes the state of the utterance. The state marked with blue colour (see fig. 4) follows the state of the utterance, which also excludes compliance with the situation depicted in figure 1.

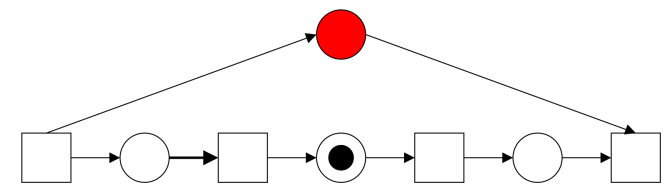

Figure 3 Net presentation of the Lithuanian sentence Tomas skaito seneliams laiškus. 'Tom is reading letters to his grandparents.', containing the present tense verbal form skaito

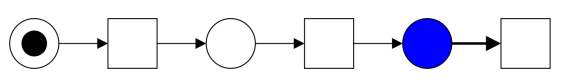

Figure 4 Net presentation of the Lithuanian sentence Tomas skaitys seneliams laiškus. 'Tom will be reading letters to his grandparents.', containing the future tense verbal form skaitys

On the basis of the net presentations in figures 3 and 4, it should be concluded that the net in figure 1 explicitly excludes the interpretations presented in figures 3 and 4 . State 1 preceding the state of the utterance is a sufficient condition for excluding the convergence (similarity) of the net presentations of sentences containing the verbal form with this suffix and of other verbal forms, i.e. forms of the present tense and the future tense (used here with the meaning of the present tense and the future tense). 
3 Meaning resulting from the use of other Lithuanian past tense forms in comparison with the meaning brought in by verbal forms with the grammatical suffix -dav-

As it turns out, the net interpretation described in figure 1 sufficiently distinguishes the meaning of sentences containing the verbal form with the suffix -dav-from sentences containing time-reference forms, such as the present tense forms and the future tense forms. However, the question if the net described in figure 1 explicitly identifies the meaning of sentences being of our interest, as opposed to those not containing the verbal forms with the suffix -dav-, is still not settled. So, the verbal forms with the suffix - dav- are not the only verbal forms to express the meaning of the past tense in the Lithuanian language.

\subsection{Net interpretation of Lithuanian sentences with the single past tense form}

Let us now check whether the net presentation of sentences containing the single past tense forms differs from the interpretation depicted in figure 1. For that purpose we will create nets for the Lithuanian sentences Tomas skaite seneliams laiškus. 'Tom was reading letters to his grandparents.' (see fig. 5) and Tomas perskaité seneliams laiškus. 'Tom read letters to his grandparents.' (see fig.6).

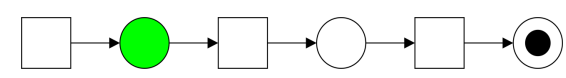

Figure 5 Net presentation of the Lithuanian sentence Tomas skaite seneliams laiškus. 'Tom was reading letters to his grandparents.', containing the single past tense form skaite

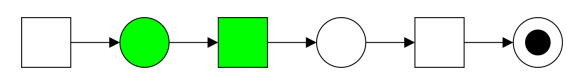

Figure 6 Net presentation of the Lithuanian sentence Tomas perskaite seneliams laiškus. 'Tom read letters to his grandparents.', containing the single past tense form perskaite

As results from the net combination of figures 1 and 5 , the net presentation of the sentences Tomas skaitydavo seneliams laiškus. and Tomas skaitè seneliams laiškus. is identical. In both cases, the states preceding the state of the utterance were distinguished (with green colour). However, why does the net presentation of the sentence Tomas perskaitė seneliams laiškus., depicted in figure 6, differ from that depicted in figure 5? After all, both the forms perskaite and skaite are of the same single past tense. The semantic difference results from the aspect of the specific single past tense form. The Lithuanian compound perskaite (event $1^{2}$ ) is a form for

\footnotetext{
${ }^{2}$ Two kinds of events and two kinds of states are distinguished in the-aspect-and-tense description. Event 1 is a single event, whilst Event 2 is a sequence (s) of states and events terminating with an event. Likewise, we distinguish the states: State 1 is a single state, whilst State 2 is a sequence (s) of states and events terminating with a state, cf. (Dimitrova, Koseska, Roszko, D. \& Roszko, R., 2014).
} 
which perfectivity value is assigned, whereas for the form skaite (state 1 or state 2) - imperfectivity value is assigned.

3.2 An attempt to diversify the meanings of Lithuanian sentences with the imperfective form of the single past tense and with the verbal form containing the grammatical suffix -dav-

As it turns out, the net presentation depicted in figure 1 is not sufficient to distinguish the meanings of sentences containing the verbal form with the suffix -davfrom sentences constructed by means of the verbal form of the single past tense in the imperfective aspect (see fig. 5). Therefore, it is still necessary to elaborate a net depicting the meanings of the sentences of, for the time being, identical net presentations: Tomas skaitydavo seneliams laiškus. and Tomas skaite seneliams laiškus.

3.3 Two variants of the net representations of Lithuanian sentences constructed on the basis of the single past tense forms in the so-called imperfective aspect

A detailed analysis of sentences containing the Lithuanian single past tense form in the so-called imperfective aspect reveals two semantic variants being reflected in figures 7 and 8.

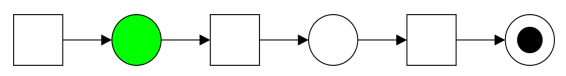

Figure 7 Net presentation of the Lithuanian sentence Tomas skaite seneliams laiškus. 'Tom was reading letters to his grandparents.' (precisely then) '(durative meaning)

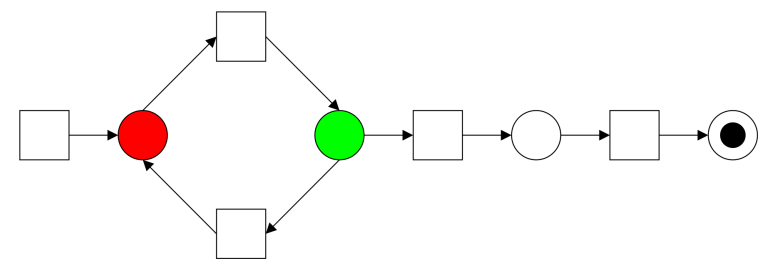

Figure 8 Net presentation of the Lithuanian sentences Tomas skaite seneliams laiškus. 'Tom was reading letters to his grandparents.' (more than once) (frequentative meaning) and Tomas skaitinèjo seneliams laiškus. 'Tom was reading letters to his grandparents.' (more than once)'

In the first variant, introduced in figure 7 , a precise, single moment in the past, in which Tom is reading letters to his grandparents, is expressed. This way of using the Lithuanian single past tense form in the so-called imperfective aspect can be determined as durative. In the other variant, introduced in figure 8 , the sequence of the past states is to be seen. The states «Tom is reading letters to his grandfathers» (marked with green) appear alternately with other past states (marked with red), for which it is true that «Tom is not reading letters to his grandparents». This 
usage can be determined as frequentative. Due to the fact that the two meanings distinguished above are conveyed by sentences in the identical formal aspect, the usage results from context or situation.

3.3.1 Net interpretation of Lithuanian sentences with the single past tense form containing the frequentative suffix

The net presentation introduced in figure 8 also corresponds with the meaning of Lithuanian sentences containing single past tense forms in the so-called imperfective aspect with the frequentative suffix, e.g. Tomas skait-inejj-o seneliams laiškus. The presence of the frequentative suffix concurrently excludes using the single past tense form in the so-called imperfective aspect in a durative meaning. However, it should be concluded that in Lithuanian local dialects this interpretation is possible, which is mentioned by D. Roszko in her monograph of the Puńsk local dialect (Roszko, D., 2014).

\section{An extended net presentation of sentences constructed on Lithuanian verbal forms with the grammatical suffix -dav-}

On the basis of the studies conducted earlier, the results of which were presented in (Roszko, D. \& Roszko, R., 2007), the use of the Lithuanian form of the so-called iterative past tense (which is described here as verbal forms with the grammatical suffix -dav-) is connected with iteration. So, the net interpretation depicted in figure 8 corresponds with the interpretation of sentences containing verbal forms with the grammatical suffix -dav-. Therefore, other essential features should be indicated in the configuration of past states for at least one type of sentences, or for sentences such as Tomas skaitè seneliams laiškus. (frequentative meaning) or Tomas skaiydavo seneliams laiškus.

However, if it turned out that it was not possible to indicate any essential features from the point of view of the aspect-tense features distinguishing the meanings of both types of sentences, then it should be:

(a) recognized that the net depicted in figure 8 represents the ultimate net presentation of Lithuanian sentences containing verbal forms with the grammatical suffix - dav-

(b) declared that there exists synonymy between the aspect-tense meanings of sentences containing either the single past tense form (in the so-called imperfective aspect, used in a frequentative meaning) or the iterative past tense form (with the characteristic grammatical suffix -dav-).

However, there exists a feature of sentences with the past tense form containing the grammatical suffix - $d a v$-, which allows us to develop the net against the aspect-tense element. So, two sequences interconnected with each other should be distinguished in the sentences in question, which was demonstrated in (Roszko, D. \& Roszko, R., 2007; Roszko, R., 2007). The first of the sequences is always determined within the sentence. In the model sentence it is a sequence consisting of two states and two events, (see fig. 9). State 2 distinguished with green in the sequence is «Tom is reading letters to his grandparents», state 4 not distinguished 
— «Tomas is not reading letters to his grandparents». Event 1 simultaneously ends state 4 and begins state 2 . Event 3 ends state 1 and begins state 4 .

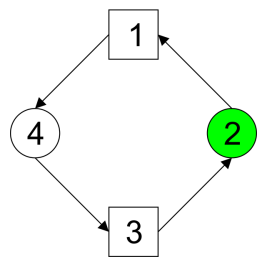

Figure 9 Sequence 1

Sequence 2, rarely expressed in the sentence, often read out from context or situation, assumes the following form (see fig. 10).

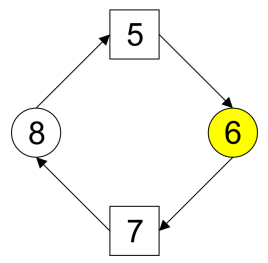

Figure 10 Sequence 2

State 6 - distinguished with yellow in the sequence - is concurrent with the state «Tomas is reading letters to his grandparents» (see state 2 in fig. 9). State 8 , not distinguished, is concurrent with the state «Tomas is not reading letters to his grandparents». Event 5 simultaneously terminates state 8 and begins state 6 . Event 7 terminates state 6 and begins state 8 .

The sequences depicted in figures 9 and 10 should be interconnected. It is assumed that the key element connecting both sequences is the event beginning the state «Tomas is reading letters to his grandparents» (event 2 in fig. 9) and the state concurrent with it (event 6 in fig. 10), which is depicted in figure 11.

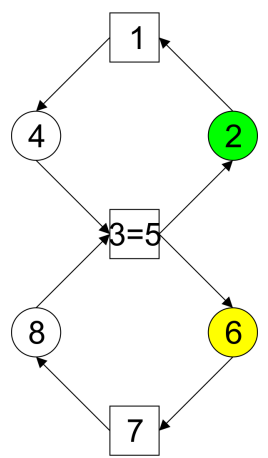

Figure 11 Interconnected sequences 1 and 2 
Interconnected sequences (see fig. 11) are recognized as the development of the state distinguished with green in figure 1 . As a result of the replacement, the configuration net presented in figure 12 comes into effect.

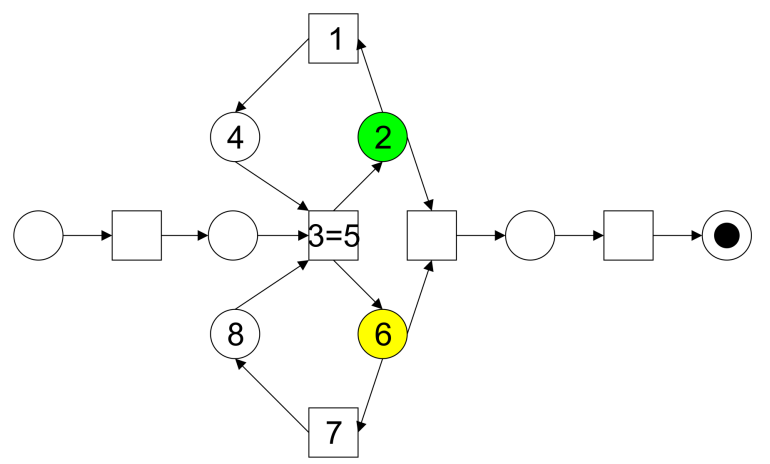

Figure 12 Extended net presentation of the Lithuanian sentence Tomas skaitydavo seneliams laiškus. ' (Always when 6) Tom was reading letters to his grandparents.'

A further special feature of sentences containing the verbal form with the grammatical suffix - dav-consists in situating the described states in a clearly marked period, which is characterized by a considerable distance from the state of the utterance. These features can also enter a net presentation (see fig. 13).

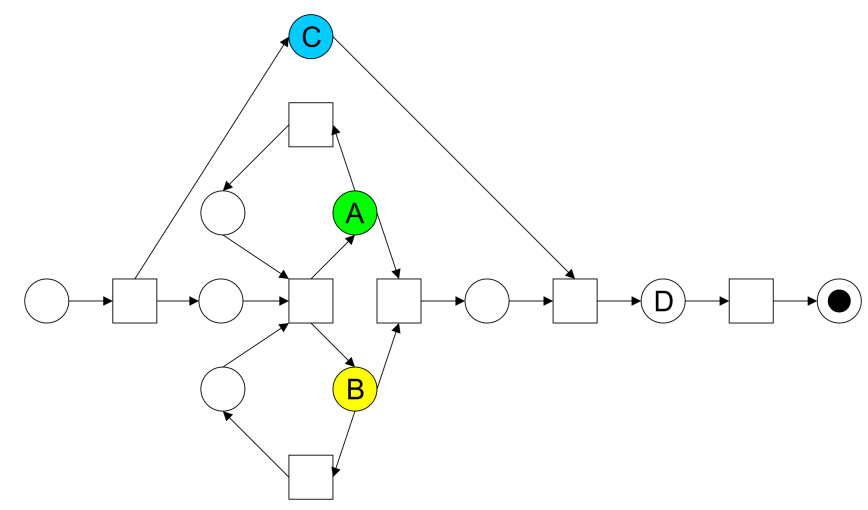

Figure 13 Ultimate extended net presentation of the Lithuanian sentence Tomas skaitydavo seneliams laiškus. '(Always when B) (in period C) Tomas was reading letters to his grandparents.'

In figure 13 state A marked with green colour is the state «Tomas is reading letters to his grandparents». State B marked with yellow colour is the state concurrent with the above-mentioned one. This state (B) is being read out from the context or the situation. For example, it is possible to describe this state as «Tomas is visiting his grandparents». So, it is possible to claim that when Tomas visits his grandparents, 
he always reads letters to them. Generalizing the meaning, the interpretation should be as follows: When B occurs A always happens. This interpretation of sentences explicitly indicates general quantification meanings (comp. Roszko, R., 2004), resulting from using the past tense forms with the grammatical suffix -dav-. State $\mathrm{C}$ distinguished with blue in the net presentation in pattern 13 marks the boundaries of the period for which it is true that when B occurs A always happens. Whereas, state $\mathrm{D}$ emphasizes a substantial distance in time between the states regularly repeated and the state of the utterance. In other words, the states described in the sentences (containing the past tense forms with the grammatical suffix -dav-) terminated long before the state of the utterance.

\section{Summary}

The net interpretation of the meaning of Lithuanian sentences containing verbal forms with the grammatical suffix - dav- reveals a crucial component element: general quantification. With regards to Lithuanian sentences containing the imperfective single past tense forms (used in a frequentative meaning, including one of many possible frequentative suffixes) the most significant element is quantitative quantification marking, whereas in sentences containing iterative past tense forms with the grammatical suffix - dav- the most significant element is range quantification marking. Quantitative marking, also found in the sentences, has a secondary aspect.

\section{References}

Dimitrova, Koseska, Roszko, D., \& Roszko, R. (2014). Trilingual Aligned Corpus Current State and New Applications. Cognitive Studies / Études Cognitives, 14, 2532. doi: 10.11649/cs.2014.005.

Guentchéva, Z. (2003). Remarques sur le concept de borne dans le domaine aspectotemporel. Studia kognitywne / Études cognitives, 5, 97-114.

Koseska, V. (2014). Semantics, Contrastive Linguistics and Parallel Corpora. Cognitive Studies / Études Cognitives, 14, 97-112. doi: 10.11649/cs.2014.009.

Koseska, V., \& Mazurkiewicz, A. (2010). Time Flow and Tenses. Warsaw: SOW.

Mazurkiewicz, A. (1986). Zdarzenia i stany: elementy temporalności. In Studia gramatyczne bułgarsko-polskie (Vol. I, Temporalność, pp. 7-21). Wrocław: Ossolineum.

Petri, C.A. (1962). Kommunikation mit Automaten. / (1966). Communication with Automata, Technical Report RADC-TR-65-377, Rome Air Dev. Center, New York.

Roszko, D. (2014). Zagadnienia kwantyfikacyjne i modalne w litewskiej gwarze puńskiej (na tle literackich języków polskiego i litewskiego). Warszawa: SOW.

Roszko, D., \& Roszko, R. (2007). Funktsii litovskogo proshedshego mnogokratnogo vremeni (ruskie sootvetstviia)). Valoda, Valoda dažādu kultūru kontekstā, Zinātnisko rakstu krājums, XVII. Daugavpils: Daugavpils Universitātes, Akadēmiskais apgāds „Saule“, 200-207.

Roszko, R. (2004). Semantyczna kategoria określoności/nieokreśloności w języku litewskim ( $w$ zestawieniu z językiem polskim). Warszawa: SOW.

Roszko, R. (2007). On automated translation from Lithuanian to Polish. In Proceedings of the Jubilee International Conference on Mathematical and Computational Linguistics, dedicated to the 30th anniversary of the Mathematical Linguistics Department, Institute of Mathematics and Informatics - BAS. 6 July, 200\%, Sofia, Bulgaria (pp. 53-57). Sofia. 
Satoła-Staśkowiak, J. (2010). Polsko-bułgarskie odpowiedniości przekładowe czasów przeszłych, Warszawa: SOW.

Sosnowski, W. (2011). Analytic Tendencies in Modern Polish and Russian. Cognitive Studies / Études Cognitives, 11, 97-108.

This is an Open Access article distributed under the terms of the Creative Commons Attribution 3.0 PL License (http://creativecommons.org/licenses/by/3.0/pl/), which permits redistribution, commercial and non-commercial, provided that the article is properly cited.

(C) The Author(s) 2014.

Publisher: Institute of Slavic Studies PAS \& University of Silesia in Katowice 